\title{
No Stress System Requires Recursive Feet*
}

\author{
Chris Golston \\ California State University Fresno \\ chrisg@csufresno.edu
}

Received: September 15, 2020

Accepted: June 29, 2021

\begin{abstract}
A recursive foot is one in which a foot is embedded inside another foot of the same type: e.g., iambic $\left({ }_{\mathrm{ia}} \sigma\left({ }_{\mathrm{ia}} \sigma \sigma \sigma\right)\right)$ or trochaic $\left({ }_{\mathrm{tr}}\left({ }_{\mathrm{tr}} \sigma \sigma \sigma\right) \sigma\right)$. Recent work has used such feet to model stress systems with full or partial ternary rhythm, in which stress falls on every third syllable or mora. I show here that no stress system requires recursive feet, that phonological processes in such languages likely don't either, and that the notion of recursive foot is theoretically suspect.
\end{abstract}

Keywords: recursive feet; stress; ternary rhythm

Resum. Cap sistema accentual requereix peus recursius

Un peu mètric recursiu és aquell que està incrustat dins d'un altre peu del mateix tipus: p. ex., un peu recursiu iàmbic $\left({ }_{\mathrm{ia}} \sigma\left({ }_{\mathrm{ia}} \sigma \sigma \sigma\right)\right)$ o un peu recursiu trocaic $\left({ }_{\mathrm{tr}}\left({ }_{\mathrm{tr}} \sigma \sigma \sigma\right) \sigma\right)$. Alguns treballs recents han fet servir aquest tipus de peu per modelar sistemes accentuals amb ritme ternari total o parcial, en què l'accent recau sobre cada tercera síl·laba o mora. En aquest article mostro que cap sistema accentual requereix peus recursius, que els processos fonològics d'aquestes suposades llengües no hi fan referència, i que la noció de peu recursiu és sospitosa des d'un punt de vista teòric.

Paraules clau: peus recursius; accent; ritme ternari

\section{Table of Contents}
1. Introduction
4. Against recursive feet
2. The core languages
5. Conclusion
3. Less convincing languages
References

* Thank you to audiences at the 2019 FiNo conference in Edinburgh, especially Patrick Honeybone, Pavel Iosad, Bob Ladd, Tomas Riad, Jade Sandstedt, and Olga Urek; at CSU Fresno, Sean Fulop, Zach Metzler, John Simonian, and Jeremy Treadwell; and at OCP 17 in Warsaw, Markus Pöchtrager and Tobias Scheer. Help from Megan Crowhurst (Cayuvava), Shyamal Das (Tripura Bangla) and Pärtel Lippus (Estonian) is also gratefully acknowledged here. Thanks above all to Trevor Driscoll, René Kager, Wolfgang Kehrein, Martin Krämer, Violeta Martínez-Paricio, and an anonymous reviewer at $C J L$, all of whom gave me feedback on earlier drafts that greatly improved the version you're reading. Errors are of course my own and the thanks I owe to these people shouldn't be taken as agreement on their part. 


\section{Introduction}

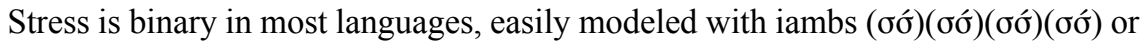
trochees $(\sigma \sigma)(\sigma \sigma \sigma)(\sigma \sigma)(\sigma \sigma \sigma)$. A handful of languages, however, have ternary (sub-) patterns that are more challenging. There are two approaches to ternary rhythm in the literature. A foot-based strategy involves ternary feet of some sort, e.g., amphi-

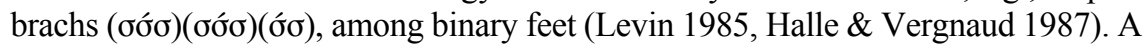
parsing-based strategy involves skipping a syllable between the iambs or trochees

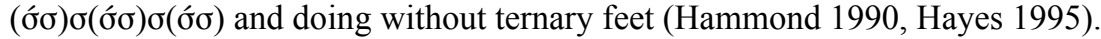

Based on earlier work, Martínez-Paricio \& Kager ('MPK' 2015) argue for adding 'recursive' trochees and iambs to binary trochees and iambs. These internally layered ternary (ILT) feet consist of a binary foot plus an 'adjunct' syllable to the left or right:
(1) 'recursive' trochees:
$((\sigma \sigma \sigma) \sigma),(\sigma(\sigma \sigma \sigma))$
'recursive' iambs:
$((\sigma \sigma) \sigma),(\sigma(\sigma \sigma))$

They base their claims primarily on three languages - Chugach Alutiiq Yupik, Tripura Bangla, and Cayuvava - but apply it typologically to cover all stress systems with ternary stress patterns.

Feet provide domains for phonological processes and a mechanism for locating stress within words. I focus primarily on the second issue here and argue that no stress system requires ternary feet to describe it. The claim has been made before (Kager 1993, Hayes 1995, Elenbaas \& Kager 1999, Houghton 2006, et alii multi) but the complicating factors that ILT feet bring up have not been discussed critically since they were worked out in Kager 2012, Martínez-Paricio 2013, and MPK 2015, 2016, especially the issue of recursion (cf. Itô \& Mester 2009, Selkirk 2011, Bennett 2012, Elfner 2012).

I'll argue here that ILT feet are neither needed for the stress data (\$2-3) nor a good idea more generally (\$4). I will not address whether ILT feet provide a good way of describing stress windows (Kager 2012), but hope to address this in future work.

\section{The core languages}

Rice notes that Chugach Alutiiq Yupik, Tripura Bangla, and Cayuvava

... are the clearest examples of ternary rhythm that have been uncovered to this point. The languages include some very long words, and even in the quantity-sensitive languages, there are words consisting of long strings of light syllables. The expert fieldworker's transcriptions of those strings indicate stressed syllables which are separated by two unstressed syllables. This is the empirical basis for the claim that ternary rhythm is a real phenomenon and that a metrical theory of stress assignment must have formal tools that can generate such patterns. (Rice 2011: 1230-1)

I'll show that none of these languages requires ternary feet if we assume that some mechanism keeps the number of feet minimal. MPK's own 'intervention' constraints ALIGN-L and ALIGN-R do this admirably, as we can see with a specific instance of their ALIGN-L $\mathrm{L}_{\max }$, a non-gradient fully categorical constraint (McCarthy 2003): 
(2) $\operatorname{AligN}_{-L}\left(\left[\mathrm{Ft}_{\max }\right]_{\omega}, \mathrm{Ft}, \omega\right)\left(\mathrm{ALIGN}_{-\operatorname{Lmax}}\right)$

For every maximal foot FTMAX, assign a violation mark if some foot intervenes between FTMAX and the left edge of its containing $\omega$.

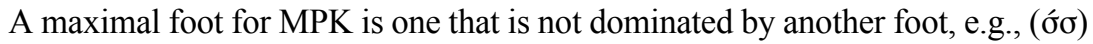
and the outer foot in $((\sigma \sigma) \sigma)$; a minimal foot is one that doesn't dominate another foot, e.g., ( $(\sigma \sigma)$ and the inner foot in $((\sigma \sigma) \sigma)$; thus $(\dot{\sigma} \sigma)$ is both maximal (not dominated) and minimal (not dominating) for them. Given enough syllables, ALIGN-L $\mathrm{L}_{\max }$

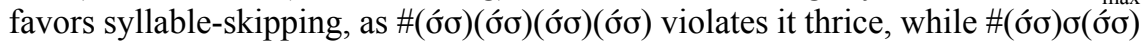
$\sigma(\sigma \sigma)$ violates it only twice. The insight here is due to Ishii (1996: 98ff), who first saw that less feet mean better alignment overall.

An anonymous reviewer asks if any kind of alignment constraint would do the trick. The answer is a qualified yes: any constraint violated by the presence of a (misaligned) foot favors a minimal number of feet because harmony increases as the number of (misaligned) feet decreases. Ishii's original point was made with constraints based on Generalized Alignment (McCarthy \& Prince 1993), where the number of violations always increases with the number of misaligned feet. But the point holds equally of Relation-Specific Alignment constraints (Hyde 2012), which assess alignment violations in terms of three arguments (the two pieces that are aligned and the piece that separates them), since these track inter alia the number of misaligned feet. It also holds of Interventionist Alignment constraints (Ellison 1994, McCarthy 2003, MPK), as we have just seen: every additional misaligned foot makes a candidate worse, making less feet a better option when alignment is high-ranked.

MPK use constraints that align and thus minimize minimal (undominating) feet to get ternary stress; and they use constraints that align and thus minimize nonminimal (dominating) feet to get binary stress. Each intervention constraint shares 'the economising function of the other alignment constraint: whereas ALIGN-L/R ${ }_{\max }$ minimises the number of maximal feet in general, ALIGN-L $/ R_{\min }$ minimises the number of maximal feet that are minimal, maximising the emergence of recursive feet' (MPK 2015: 470-1).0

Consider an $8 \sigma$ word, following the discussion in MPK, where a minimal foot is one that does not dominate another foot, e.g., (бo):

(3) Ternary stress via ALIGN $_{\text {min }}$

\begin{tabular}{|r|c|c|}
\hline & ALIGN-L $_{\min }$ & ALIGN- $_{\min }$ \\
\hline$((\sigma \sigma \sigma) \sigma)((\sigma \sigma) \sigma) \sigma \sigma$ & & \\
\hline$(\sigma \sigma \sigma)((\sigma \sigma) \sigma)((\sigma \sigma) \sigma)$ & & $* !$ \\
\hline$((\sigma \sigma) \sigma)((\sigma \sigma) \sigma)(\sigma \sigma)$ & $* !$ & \\
\hline$(\sigma \sigma)(\sigma \sigma \sigma)(\sigma \sigma)(\sigma \sigma)$ & $* ! * *$ & $* *$ \\
\hline
\end{tabular}


The inner foot in $((\sigma \sigma) \sigma)$ is not subject to Align ${ }_{\min }{ }^{1}$ and thus fares better than

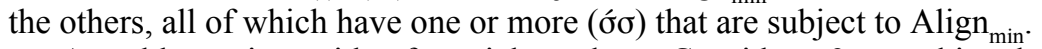

A problem arises with a factorial typology. Consider a $9 \sigma$ word in a language where ALIGN- $\mathrm{L}_{\min }$ outranks ALIGN- $\mathrm{L}_{\max }$, a constraint that 'can only affect (minimise) the number of feet' (p. 491). The ranking predicts stress on every fourth syllable:

(4) Quaternary stress via a factorial typology

\begin{tabular}{|r||c|c|c|}
\hline & ALIGN-L $_{\min }$ & ALIGN-R $_{\min }$ & ALIGN-L $_{\max }$ \\
\hline$\sigma^{*}((\sigma \sigma) \sigma) \sigma((\sigma \sigma) \sigma) \sigma \sigma$ & & & $*$ \\
\hline$((\sigma \sigma) \sigma)((\sigma \sigma) \sigma)((\sigma \sigma)) \sigma)$ & & $* * *$ & $* * !$ \\
\hline$(\sigma \sigma \sigma)(\sigma \sigma \sigma)(\sigma \sigma)(\sigma \sigma) \sigma$ & $* ! * *$ & $* *$ \\
\hline
\end{tabular}

Undominated ALIGN- $\mathrm{L}_{\min }$ and ALIGN- $\mathrm{R}_{\min }$ make all feet ternary, keeping the third candidate at bay, but ALIGN- $\mathrm{L}_{\text {max }}$ keeps the overall number of feet low, picking the candidate with quaternary stress. The same bombed candidate wins if we replace ALIGN-L $\mathrm{L}_{\max }$ with ALIGN-L $\mathrm{L}_{\text {non-min }}$, which minimizes the number of ternary feet, again selecting the first candidate over the second. Thus, a factorial typology of the ALIGN constraints in MPK 2015 wrongly predicts languages with quaternary stress. [An anonymous reviewer asks if the absence of quaternary stress is a real typological observation or just the result of words generally being too short to exhibit stress on every fourth syllable. I take this up in secion 4.1 with the typological claims MPK make.]

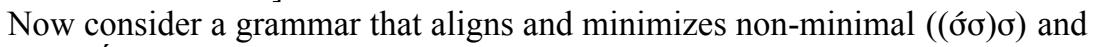
minimal $(\sigma \dot{\sigma})$ feet, preferring a small number of binary feet:

(5) Ternary stress via ALIGN-L

\begin{tabular}{|r|c|c|}
\hline & ALIGN-L $_{\text {non-min }}$ & ALIGN-L $_{\text {min }}$ \\
\hline$(\sigma \sigma \sigma) \sigma(\sigma \sigma) \sigma(\sigma \sigma) \sigma$ & & $* *$ \\
\hline$(\sigma \sigma)(\sigma \sigma \sigma)(\sigma \sigma \sigma)(\sigma \sigma) \sigma$ & $* !$ & $* * !$ \\
\hline$((\sigma \sigma) \sigma) \sigma((\sigma \sigma) \sigma) \sigma \sigma$ & $* ! *$ & $* * *$ \\
\hline$((\sigma \sigma) \sigma)((\sigma \sigma \sigma) \sigma)((\sigma \sigma \sigma) \sigma)$ & & $* *$ \\
\hline
\end{tabular}

1. The inner foot in $((\sigma \sigma \sigma) \sigma)$ cannot be misaligned from the edges of a prosodic word because of the intervening foot-structure. See 'vertical locality conditions', p. 469. 
The candidate with ternary stress and skipped syllables wins, even if we only use constraints from MPK. The second candidate loses because it has too many binary feet; the third and fourth lose because they have ternary feet. Ternary stress does not require ternary feet, even if we use MPK's own ALIGN constraints, which promote the syllable skipping they're meant to replace.

I suggest that we return to using only binary feet, which have been very successful in modeling both binary and ternary stress, and which do not predict quaternary stress. We can use MPK's ALIGN constraints but keep all feet strictly binary $(\mu \mu$ or $\sigma \sigma)$. ALIGN promotes skipping and ternary stress, while NoLAPSE promotes no skipping and binary stress:

(6) Factorial typology

\begin{tabular}{|r|c|c|}
\hline ternary stress & ALIGN-L & NoLAPSE \\
\hline$(\sigma \sigma \sigma) \sigma(\sigma \sigma) \sigma$ & $*$ & $* *$ \\
\hline$(\sigma \sigma \sigma)(\sigma \sigma \sigma)(\sigma \sigma)$ & $* * !$ & ALIGN-L \\
\hline binary stress & NoLAPSE & $*$ \\
\hline$(\sigma ́ \sigma) \sigma(\sigma o \sigma) \sigma$ & $* ! *$ & $* *$ \\
\hline
\end{tabular}

That's the idea: use MPK's ALIGN constraints to capture ternary stress without their ternary feet.

\subsection{Chugach Alutiiq Yupik (CA)}

Published work on this important dialect of Yupik is based on Leer (1985abc). Leer (1993/1994) updates the data and generalizations, however, leading him to reject major parts of his earlier work including ternary feet:

I have spent many years working on this dialect and have in the process learned to speak it with some fluency. My observations on the phonology of this dialect are thus backed by many hundreds of hours of conversational interaction with speakers as well as teaching of the language and orthography, in the process of which I was constantly checking my mental construct of the phonological rules against what I was hearing. I am therefore reasonably confident of the observational accuracy of the present analysis. (1993: 46)

Leer bases his analysis on 'the phonetic clues to foot structure- stress, pitch, and the boundary effect' and shows that they are fully explained by bimoraic iambs from left to right, 'leaving a stray mora between feet where possible' (1993: 66). Note that codas do not make syllables heavy: 
(7) Primary (á) stress

(akú)taq

(akú)(taá)

'Aleut ice cream'

(akú)ta(miní)

(akú)ta(tuá)

(akú)ta(tugán)

(akú)ta(tuqú)ni

'his/her Aleut ice cream'

'in his/her own Aleut ice cream'

'eat some Aleut ice cream!'

'if he/she eats some Aleut ice cream'

(akú)(tatú)(quút)

'if he/she (REFL)eats some Aleut ice cream'

(akú)ta(tuqú)(tagán)

'if you eat some Aleut ice cream'

(akú)ta(tuqú)ta(quní)

'if he/she is going to eat some Aleut ice cream'

(akú)ta(tuqú)ta(quút)

(akú)(taí)tuq

(akú)(taí)(tuá)

(akú)(taí)(tagán)

(akú)(taí)ta(qamí)

(akú)(taí)ta(qaút)

'if he/she (REFl) is going to eat some Aleut ice cream'

'if you are going to eat some Aleut ice cream'

'he/she doesn't have any Aleut ice cream'

'I don't have any Aleut ice cream'

'whenever he/she doesn't have any Aleut ice cream'

'whenever he/she (REFL) doesn't have any Aleut ice cream'

'whenever you don't have any Aleut ice cream'

CA has stressed (á) and stressless (a) syllables and nothing else; his 1985 analysis had strong, weak, and stressless syllables. Leer captures CA stress with $(\dot{H})$ and (LĹ) iambs and has no need for ternary feet. Note that every word begins with a foot, ALIGN-L $(\omega, \varphi)$, and so no word in CA has stress on every third syllable.

I attribute the drive to parse as much as possible to PARSE-2 (Kager 1994) whereby 'one of two adjacent stress units must be parsed by a foot':

(8) (akú)ta(tuqú)ni 'if he/she (REFL) eats some Aleut ice cream'

\begin{tabular}{|c|c|c|c|}
\hline & PARSE-2 & ALIGN-L $(\omega, \varphi)$ & Align-L \\
\hline$(\mathrm{LL}) \mathrm{L}(\mathrm{LL}) \mathrm{L}$ & & & $*$ \\
\hline (LĹ)(LĹ)(LĹ) & & & $* * !$ \\
\hline L(LĹ)L(LĹ) & & $* !$ & $*$ \\
\hline (LĹ)LL(LĹ) & $* !$ & & $*$ \\
\hline
\end{tabular}

Too many feet kill the second candidate, the lack of an initial foot kills the third, and a pair of stray syllables kills the fourth. ALIGN-L makes a difference when strings of lights can be parsed in various ways: it prefers L(LL)L over (LL) (LL), minimizing feet.

Heavy syllables are always stressed in CA (due to PARSE-2 - the stress unit is the mora), which obscures any ternary pattern: 
(9) (akú)(taí)ta(qaút) 'whenever you don't have any Aleut ice cream'

\begin{tabular}{|c|c|c|c|}
\hline & PARSE-2 & Align-L $(\omega, \varphi)$ & AligN-L \\
\hline$(\mathrm{LL})(\mathrm{H}) \mathrm{L}\left(\mathrm{H}^{\prime}\right)$ & & & $* *$ \\
\hline L(LH́)L(H́) & & $* !$ & $*$ \\
\hline (LĹ)(H)LH & $* !$ & & $*$ \\
\hline
\end{tabular}

As is already clear from Leer (1993) or Kager (1993), then, stress in CA doesn't require ternary feet.

Leer shows that pitch in CA doesn't either (using H, M, L for Leer's 3, 2, 1 tones):

(10) Assignment of pitch to syllables (p.102)

a. A syllable whose vowel is dominated directly by $\Phi^{\prime}$ is assigned $\mathrm{H}$.

b. A syllable whose vowel is dominated directly by $\Phi$ is assigned $\mathrm{M}$.

c. A stray syllable is assigned $\mathrm{L}$, as is word boundary.

d. The pitch of the weak syllable of a disyllabic iambic foot is intermediate between those of the syllables (or word boundary) on either side.

Parentheses below mark Leer's $\mu \mu$ feet $(\Phi=$ one H or two L syllables $)$ and square brackets mark his $\mu \mu \mu \mu$ 'pitchgroups' $\left(\Phi^{\prime}=\right.$ two $\left.\Phi\right)$. Pitch is assigned as above, where the final syllable of a pitchgroup is High (ó), the final syllable of a foot is Mid $(\bar{\sigma})$, and every stray syllable is Low toned ( $(\bar{\sigma})$ :

(11) Hi (á), Mid (ā) and Low (à) tones
(akū)tàq
'Aleut ice cream'
[(akū)(taá)]
'his/her Aleut ice cream'
(akū)tà(min̄i)
'in his/her own Aleut ice cream'
(akū)tà(tuā)
'eat some Aleut ice cream!'
(akū)tà(tugān)
'if he/she eats some Aleut ice cream'
(akū)tà(tuqū)nì
'if he/she (REFL) eats some Aleut ice cream'
[(akū)(tatú)](quūt)
'if you eat some Aleut ice cream'
(akū)tà[(tuqū)(tagán)] 'if he/she is going to eat some Aleut ice cream'
(akū)tà(tuqū)tà(qunī) 'if he/she (REFL) is going to eat some Aleut ice cream'
(akū)tà(tuqū)tà(quūt) 'if you are going to eat some Aleut ice cream'
$[(\mathrm{aku})($ taí) $)$ tùq
'he/she doesn't have any Aleut ice cream'
$[($ akū $)($ taí) $]($ tuā $)$
'I don't have any Aleut ice cream'
$[(\mathrm{aku})($ taí)](tagān)
'whenever he/she doesn't have any Aleut ice cream'
$[(\mathrm{aku})($ taí) $]$ tà(qamī)
'whenever he/she (REFL) doesn't have any Aleut ice cream'
$[(\mathrm{aku})$ (taí) $]$ tà(qaūt)
'whenever you don't have any Aleut ice cream'

As Leer points out, the tone data undermine his 1985 analysis, which required feet, pitchgroups, and a ternary 'superfoot' $((\dot{H}) \dot{\mathrm{L}})$ or $((\mathrm{L} \dot{\mathrm{L}}) \mathrm{L})$ with two stresses: 
[M]y earlier treatment of Alutiiq involved a level intermediate between foot and pitchgroup. Stray syllables were joined with the foot to their left to form a 'superfoot'. This was a superficial mop-up procedure whose only purpose was to ensure that all syllables in the word were part of some prosodic structure, since metrical theory as I understood it disapproved of word-internal stray feet. I have since concluded that the 'superfoot' level is unnecessary; it just clutters up the structural representation without imparting new information.

Furthermore, dispensing with the 'superfoot' permits an elegant statement of the rule for pitchgroup formation. In Leer 1985c I said that right-headed pitchgroups are formed over pairs of superfeet "if $\mathrm{SF}_{1}$ [the first member of the pair] is identical with the foot it dominates (i.e. where there is no weak syllable appended to the foot)" (p. 168). This statement is flawed by the fact that I was forced to appeal to the internal makeup of the prosodic unit over which the new structure (i.e. the pitchgroup) is formed. The problem is here obviated simply by doing away with the 'superfoot'. (1993: 103-104)

We can dispense with Leer's pitchgroups, as well, based on a proposal by Hewitt (1999), who suggests that CA has a dissimilation process that avoids sequential H tones (which are called M tones in Leer 1993/1994). We can see the process at work below where the second $\mathrm{M}$ tone on [kūtaī] dissimilates to $\mathrm{H}$ [kūtaí] to avoid violation of the OCP (Leben 1973):

(12) $(\mathrm{akū})($ tāi) tà(qaūt)

\section{(akū)(taí)tà(qaūt) 'whenever you don't have any Aleut ice cream'}

The OCP requires only adjacency of the two $M$ tones, not a special pitchgroup constituent, as Leer has it. However the process is described, it's worth noting that Leer's data obeys the OCP not just here but with all tones: the data in (11) contain no adjacent identical tones of any kind.

Syllable-skipping interacts nicely with the OCP as well: adjacent feet with M-tones $(\sigma \bar{\sigma})(\sigma \bar{\sigma}) \sigma$ would violate the OCP, but skipping a syllable fixes that, $(\sigma \bar{\sigma})$ $\grave{\sigma}(\sigma \bar{\sigma})$, since stray syllables surface as L $(\grave{\sigma})$. This is equally true if either foot is a heavy syllable, $(\bar{\sigma})(\sigma \bar{\sigma}) \sigma$ or $(\sigma \bar{\sigma})(\bar{\sigma}) \sigma$, where an intervening stray syllable breaks up the $\mathrm{M}$ tones with a L: $(\bar{\sigma}) \grave{\sigma}(\sigma \bar{\sigma})$ or $(\sigma \bar{\sigma}) \grave{\sigma}(\bar{\sigma})$. We have already seen what happens when both feet are heavy syllables: $(\bar{\sigma})(\bar{\sigma})$ dissimilates to $(\bar{\sigma})(\sigma)$.

A final slight modification to Leer to bring it up to date is to link stray L syllables directly to the prosodic word:

(13) Stray syllables dominated by $\omega$
$\overbrace{\varphi}^{\infty}$
a kū taí tà qaūt 'whenever you don't have any Aleut ice cream' 
Segmentally, Leer shows that consonant fortition applies within binary iambs: 'it helps the hearer by providing acoustic evidence, and it helps the speaker by providing a second type of articulatory gesture - the first being stress - with which to organize the prosodic structure' (p. 64-65). MPK note that ILT feet capture the domain for fortition too, but they do so no better than Leer's binary feet.

MPK use ILT feet to model a type of vowel lengthening in CA whereby the [u] in ((a'ku:)taq) 'a food-ABS' is much longer than the [u] in (a'ku')(ta'mek) 'a foodABL-SG'. 'The $u$ in akútaq... can be argued to be longer than the one in akútamék... due to its double-head status: the former is simultaneously the head of two feet, a minimal foot and a non-minimal foot' (2016: 8). But ternary feet aren't required here, either, as MPK point out: lengthening could simply be inhibited before fortis consonants (Hayes 1995), or before another foot.

\subsection{Tripura Bangla (TB)}

Stress in the Tripura dialect of Bangla is described in Das (2001). A native speaker of TB, Das argues for ternary stress in TB without ternary feet:

[I]n this variety of Bangla a unidirectional ternary rhythm prevails which is only occasionally forced into binary alternation on the surface due to the role of the high ranked constraint WSP requiring heavy syllables to be stressed. Ternary rhythm does not compel ternary feet however. In keeping with the current trend of discounting ternary foot as a primitive of metrical systems we have constructed binary (trochaic) feet with Weak Local Parsing, to use Hayesian terminology. That is, ternary rhythm is explained as a binary foot separated from its neighbour by an unparsed syllable. (2001: 144)

Ternary stress occurs in words with strings of Ls, as follows (p. 200-201):

\begin{tabular}{|c|c|c|}
\hline 14) $1 \sigma$ & ('bo:) $(</ b o /)$ & 'bride' \\
\hline $2 \sigma$ & ('bari) & 'home' \\
\hline $3 \sigma$ & ('фəta)ka & 'flag' \\
\hline $4 \sigma$ & ('alo)sona & 'discussion' \\
\hline $5 \sigma$ & ('əфо)ri(,n॰to) & 'immature' \\
\hline $6 \sigma$ & ('onu)ko(, roni)y & 'imitable' \\
\hline $7 \sigma$ & ('ono)nu(, koro)niyo & 'inimitable’ \\
\hline & ('ono)nu( kəro)ni( yota) & mitabilit \\
\hline
\end{tabular}

Most all-L words work as in CA, but not those with 4 and $7 \sigma$, which don't parse the pair of final Ls. We can account for this by requiring that pairs of stray syllables be word-final/initial (cf. MPK's CHAIN constraints, which require that single stray syllables be word-final/initial):

(15) ALIGN-R( $\sigma \sigma)$ : Every pair of stray syllables is word-final.

The first candidate below has a word-final pair of strays, respecting ALIGN$\mathrm{R}(\sigma \sigma)$. The second and fourth have no pair of strays, but the third does, and that pair isn't word final, violating ALIGN-R( $\sigma \sigma)$ : 
(16) ('ono)nu(, koro)niys 'inimitable'

\begin{tabular}{|c|c|c|c|}
\hline & ALIGN-L $(\omega, \varphi)$ & ALIGN-R $(\sigma \sigma)$ & ALIGN-L \\
\hline$(\hat{\mathrm{L}} \mathrm{L}) \mathrm{L}(\grave{\mathrm{L}} \mathrm{L}) \mathrm{LL}$ & & & * \\
\hline 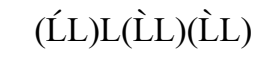 & & & $* * !$ \\
\hline (ÍL)LL(ìL)L & & *! & $*$ \\
\hline L(ĹL)L(ìL)L & $* !$ & & $*$ \\
\hline
\end{tabular}

(17) ('ono)nu(, koro)ni(,ysta) 'inimitability'

\begin{tabular}{|c|c|c|c|}
\hline & ALIGN-L $(\omega, \varphi)$ & ALIGN-R( $\sigma \sigma)$ & ALIGN-L \\
\hline$(\hat{\mathrm{L} L}) \mathrm{L}(\grave{\mathrm{L}} \mathrm{L}) \mathrm{L}(\grave{\mathrm{L} L})$ & & & $* *$ \\
\hline (ĹL)(ĹL)(ĹL)(ĹL) & & & $* * * !$ \\
\hline (ÍL)LL(L̀L)LL & & $* !$ & * \\
\hline L(ĹL)L(ĹL)(ĹL) & $* !$ & & $* *$ \\
\hline
\end{tabular}

Note that pairs of strays only occur word-finally in TB, showing that ALIGN$\mathrm{R}(\sigma \sigma)$ is inviolate. Ternary stress patterns are interrupted by heavy syllables, as Das has shown, but I will pass over this important and difficult data, partly for lack of space and partly because MPK do not treat them, and my point here is to argue against the necessity of recursive feet.

Das's argument against ternary feet (chapter 3 ) has been ignored in the literature so I'll repeat it here:

[A] voiceless velar plosive weakens to $h$ if it occurs in an open unstressed syllable immediately after a stressed syllable. $\mathrm{k}$ however retains its underlying featural identity if it stands one syllable away to the right of the stressed syllable. A ternary foot analysis has no explanation for such a variable behaviour of $k$. In terms of binary foot analysis this is a case of weakening restricted to the non-head position within a foot. (p. 145)

There are also underling $/ \mathrm{h} /$ and $/ \beta /$, so $[\mathrm{h} / \mathrm{k}]$ and $[\beta / \mathrm{b}]$ are not in strict complementary distribution (Shyamal Das p.c., July 2020). Again, the lenition of $k \rightarrow h$ and $\mathrm{b} \rightarrow \beta$ takes place in a foot-medial onset:

\begin{tabular}{|c|c|c|c|}
\hline (káha) & 'uncle' & (ćha)ki & 'alone' \\
\hline & 'aunt & (фóta)ka & 'flag \\
\hline & 'father' & (zóßa)bi & eply' \\
\hline zt & 'wife' & $(\mathrm{h}$ & lating \\
\hline a(bífkar) & 'discovery' & $\mathrm{a}($ bírßab) & vent' \\
\hline
\end{tabular}


As Das points out, 'an intra-foot non-head position is the ideal context for lenition' (p. 176).

His claim that ternary feet don't provide the right domain for lenition is true for most ternary feet. Beasley \& Crosswhite (2003) and Idsardi (2008) use flat dactyls

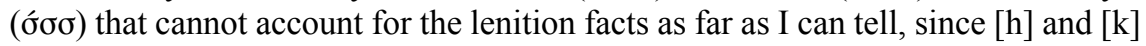
would both be intervocalic, stressless, and foot medial in (ćhaki) 'alone'. Buckley

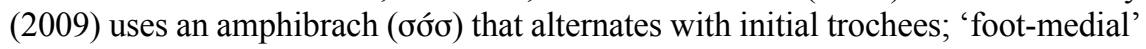
lenition mispredicts $\mathrm{k} \rightarrow \mathrm{h}$ in a word like (óno)(nukòro)niys 'imitable', where [k] is foot-medial in the amphibrach. 'Foot-medial-and-stressless' would do, so Buckley's approach is compatible with the data, if not compelling.

MPK don't discuss the lenition facts in print either but I am told that:

[W]e don't think there is need for an independent domain referred to as "foot medial". First, if we already have "foot dependent/foot head" and "foot initial/foot final", we can refer to all the subconstituents/positions within a foot without the need to postulate a fifth "domain"... [R]eferring to a medial position in any prosodic category seems a stipulation. (Violeta Martínez-Paricio, p.c., August 2020)

I don't see how the first consonant in ((Éha)ki) can be targeted as foot dependent or foot head and it isn't foot initial or foot final, so it's not clear to me how foot medial can be done away with. It could of course be foot-dependent-and-initial, but that is a fifth kind of domain that brings with it many more (see 26 below). MP suggests further that 'processes that seem to be restricted to a medial position can be described in a negative way in the sense that they do not occur, for instance, in initial position'; but banning lenition in initial position still would give us *((ćha) hi) with two fricatives rather than ((ćha)ki) with one.

\subsection{Cayuvava}

Cayuvava is the only language on the planet claimed to have stress on every third syllable of words that are long enough to have multiple stresses. Data are from Harold Key $(1961,1967,1975)$ and Mary Ritchie Key (2015), the latter an online dictionary based on Harold Key's fieldnotes, as far as I can tell. Key describes the stress system of Cayuvava as follows:

There are two degrees of phonemic stress in Cayuvava, weak and strong. Strong stress generally occurs on the antepenultimate syllable of utterances of three or more syllables, and on the initial syllable of shorter utterances. The tri-syllable stress group patterning marks strong stress from the final syllable of multi-syllable utterances. Strong stress occurs on the antepenultimate syllable and every third syllable preceding it. This appears to be a sentence-level pattern but it can be interrupted by any morpheme with phonemic strong stress. (1961: 149)

A number of issues deserve deeper treatment, including his claim that strong and weak stress are phonemic, the patterning of 'weak' stress, the large number of words that are transcribed with no stress at all, and the fact that the pattern is 
probably phrasal rather than lexical; but I will forgo these worries for now, brevity being the soul of wit, and focus on the data as generally reported:

(19) (æm)

(bí.bi)

(á.ßa)ča

a(ré.na)hi

bo.ro(čó.čo)do

(á.a)re(hó.ri)hi

a(rá.mi)ñi(ná.hi)i

a.ti(bá.ča)ri(já.a)pa

(á.ri)ča(há.hæ)ræ(rá.a)i

a(rí.ča)hi(rí.su)ru(pá.e)æ 'name (noun)'

'blood sucking bug, a chulupi'

'duck'

'this'

'kind of fruit'

'it is us'

'is clean'

'intent to tell you, sir'

'I had worked also'

'also we are grateful'

Key never proposes any kind of foot for the language but it's easy to see the same pattern here as we saw in CA and TB all-L-words, aligned now with the end of the word. If all syllables are light, we can treat the stress as antepenultimate (NonFinal > ALIGN-R) with as few extra feet as possible:

(20) (á.ri)ča(há.hæ)ræ(rǽ.a)i

'I had worked also'

\begin{tabular}{|c|c|c|c|}
\hline & PARSE-2 & NONFINAL & Align-R \\
\hline$\left(\dot{L}^{2}\right) \mathrm{L}\left(\mathrm{L}_{\mathrm{L}}\right) \mathrm{L}\left(\mathrm{L}_{\mathrm{L}} \mathrm{L}\right.$ & & & $* *$ \\
\hline$\left(\dot{L}^{\prime}\right)\left(\dot{L}^{\prime} \mathrm{L}\right)\left(\dot{L}_{\mathrm{L}}\right)\left(\dot{L}_{\mathrm{L}}\right) \mathrm{L}$ & & & $* * * !$ \\
\hline L(ĹL)L(ĹL)L(ĹL) & & $* !$ & $* *$ \\
\hline LL(ĹL)(ĹL)(ĹL)L & $* !$ & & $* *$ \\
\hline
\end{tabular}

The final candidate above has a fatal pair of unparsed syllables; the penultimate candidate has a final foot; and the antepenultimate candidate has too many feet. This leaves the first candidate, with ternary stress, as optimal. Ternary-foot solu-

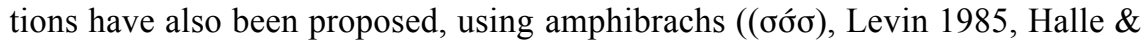

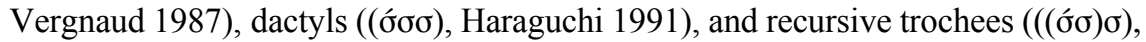
Martínez-Paricio \& Kager 2015). But none of these solutions is any more required for Cayuvava than for CA or TB. Since disyllabic words require binary feet in any case, the choice is between only binary feet or binary cum ternary feet. See Occam's Razor.

\section{Less convincing languages}

A handful of other languages have ternary stress alternations, but none as clearly as the languages we've just looked at. I'll discuss them briefly here. 


\subsection{Estonian}

Hint (1973) reports that Estonian has initial primary stress, with secondary stress that occurs on every other or every third syllable, apparently in free variation in words of $5 \sigma$ and longer. Prince argues for recursive feet based on pronunciations like ((híli)se)((màt)te)le) (1980: 519). Estonian can be pronounced with a ternary stress pattern, but for every such word a binary stress pattern exists as well (see also Eek 1990: 259ff). Thus, Estonian merely has optional ternary stress on long words and the issue is how we capture both patterns in a single analysis.

We can model this with a grammar in which the ranking of ALIGNL and NOLAPSE varies (Anttila \& Cho 1998). In the ranking where NoLAPSE $\gg$ ALIGNL we get adjacent feet, (híli)(sèmat)(tèle) 'later, all. pl.'. When ALIGNL 》 NoLAPSE we get a skipped syllable (híli)se(màtte)le. It's unclear to me how to do this with recursive feet, since the constraint rankings for a language with only binary feet (e.g., Pintupi) are quite different than those with binary and ternary feet (cf. CA):

(21) Ranking for (híli)(sèmat)(tèle) (cf. Pintupi)

AlignL/ $\mathrm{R}_{\text {unary }}$, Trochee ${ }_{\text {non-min }}$, ChainR, Iamb ${ }_{\text {non-min }}$, AlignL $/ \mathrm{R}_{\text {non-min }}$, Trochee $\gg$ ChainL $\gg$ AlignL $/ \mathrm{R}_{\max }$, AlignR $_{\min }$, AlignL $_{\text {min }}$, Iamb

(22) Ranking for ((híli)se)((màtte)le) (cf. CA) AlignL/ $R_{\text {unary }}$, Trochee ${ }_{\text {non-min }}$, ChainR, ChainL, Iamb, $\gg$ AlingL $/ \mathrm{R}_{\max }$, Align $_{\min }$, Trochee

$\gg$ AlignLR $_{\text {non-min }}$, Iamb $_{\text {non-min }}$, $\gg$ AlignL $_{\min }$

If the constraints in (21) are ordered ABCDEF $\gg G \gg$ HIJK, those in (22) are ABCGK $\gg$ FHI $\gg$ DEK $\gg$ J. Toggling between two grammars with such different rankings strikes me as improbable, though the matter deserves a much deeper look and I've barely sketched a binary analysis here.

Asu \& Lippus (2018) bring into doubt the acoustic reality of secondary stress in Estonian:

$[\mathrm{T}]$ he secondary stressed syllables in Estonian are not acoustically different from the unstressed syllables with respect to various durational, pitch-related and spectral measures normally used to investigate correlates of stress. The only exception is the unstressed syllable following the primary stressed syllable that behaves differently from other unstressed syllables. (Asu \& Lippus 2018: 605)

Their measures include onset and vowel duration; average and standard deviation of F0, and slope of F0 in the vowel; and mean intensity, spectral balance, and spectral emphasis in the vowel. 'The fact that the secondary stressed syllables did not differ from the unstressed syllables leads us to ask whether it is useful to distinguish secondary stress at all, at least in phonetic terms' (loc. cit.). Estonian doesn't provide a clear case of ternary feet, recursive or otherwise. 


\subsection{Hocak/Winnebago}

In Hocąk 'following the primary accent on the third mora, secondary accents occur on all even-numbered moras' (Miner 1989) and positioning the third-mora accent is our concern here. 'One thing that is very important to realize is that Winnebago accent is primarily pitch' (Miner 1981: 341), which for the main stress is a $\mathrm{H}$ tone. Miner shows that main stress can be placed on the peninitial syllable if the $\mathrm{H}$ tone assigned to it moves one syllable to the right (Miner 1989). Following a suggestion by Hayes (1995: 365), that Hocąk is similar to Ancient Greek (Sauzet 1989, Golston 1990), I propose that Hocąk aligns a L*H pitch accent to the stressed syllable of an initial iamb. This gives us $\mathrm{H}$ pitch on the 3 rd $\mu$ from the left. I leave a full analysis to future work, but the idea is sketched below; note that there's no need for the $\mathrm{H}$ tone to be footed:

(23) Hocąk

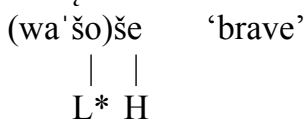

If this is right, Hocąk requires only binary feet from left to right (see Miner 1979, 1989; Hale \& White-Eagle 1980; Helmbrecht 2010, Helmbrecht \& Lehmann 2006).

\subsection{Sentani}

Sentani (Cowan 1965) has binary primary stress on the rightmost (ĹL) or (H́); ternarity shows up three syllables from the primary stress with strings of $L$ and two syllables from the primary stress as $\mathrm{H}$ syllables come into play:

(24) (ว̀də)ka(wále)

a(dilə)mi(híbe)

ha(bə̀w)noko(kále)

ə(nàjnə)ken(sín)de
'I saw thee'

'you two will collect them'

'I struck him'

'they (pl.) will throw it away'

The rest of the story involves quality-sensitivity (Kenstowicz 1997) which I'll pass over.

The little bit of ternarity in Sentani requires no ternary feet, as Hayes (1995) and Elenbaas \& Kager (1999) have shown. Right-branching amphibrachs are proposed by MPK (2015: 484), so that a(dilə)mi(híbe) is (a(dilə))(mi(híbe)), but there's no evidence I see that the stray syllables must be parsed into feet. The analysis sketched here is essentially that of Cayuvava, above, minus non-finality. Again, ILT feet are possible but not required.

\subsection{Gilbertese}

Gilbertese (Blevins \& Harrison 1999) has a ternary pattern but it isn't the kind that requires recursive feet: 'Foot-internal prominence in terms of pitch and amplitude 
is spread over the first two moras of the foot, which can be considered a bipartite head, both prominent in relation to the final mora, which is weak' (1999: 217). Consider the following, where 'acute accent indicates pitch peak; grave accent indicates loudness peak':

(25) Gilbertese feet (Blevins \& Harrison 1999: 217)

Blevins \& Harrison's analysis analysis using $\mathrm{HL}^{*}$

$\begin{array}{llll}3 \sigma & \text { (ká.mè.a) } & \text { 'dog' } & \text { ká(mè.a) } \\ 2 \sigma & \text { (má.tùu) } & \text { 'to sleep' } & \text { má(tùu) } \\ 2 \sigma & \text { (án.ti) } & \text { 'spirit, ghost' } & \text { (áñ)ti } \\ 2 \sigma & \text { (ḿ.nào) } & \text { 'kind of lobster' } & \text { ḿ(nào) } \\ 2 \sigma & \text { (bú.kìn) } & \text { 'end of' } & \text { bú(kìn) } \\ 1 \sigma & \text { (áói) } & \text { 'dew' } & \text { (áòi) }\end{array}$

This suggests a $\mathrm{HL}^{*}$ pitch accent with moraic trochees as shown to the right above (cf. 23). Longer words require one pitch-accent per foot, but most long 'words' are syntactically complex, so it's not clear what prosodic constituents are involved. Blevins and Harrison 'have yet to investigate Gilbertese above the level of the prosodic word' (p. 212).

There's no need for the H tone to fall within the foot in Gilbertese, so no need for ternary feet. Stress needs to fall within the foot, but the H tone that precedes the stressed syllable needn't mark stress. MPK use $(\mu(\mu \mu))$ feet for Gilbertese but again they aren't required by the data.

\section{Against recursive feet}

I see three general problems with recursive feet: they predict too many prosodic domains (4.1), they predict too many feet (4.2), and they are not recursive in any meaningful sense (4.3).

\subsection{Too many prosodic domains}

Binary feet provide a number of prosodic domains that have proven useful in describing fortition, lenition, lengthening, deletion, neutralization, and other processes.

(26) Binary feet: 6 prosodic domains

foot-initial foot-medial foot-final

foot-head foot-dependent stray $\sigma$

We've seen cases of each of these already: foot-initial fortition (CA), footmedial lenition (TB), foot-final lengthening (CA), attraction to foot-head (H tone in CA), attraction to foot-dependent (L tone in CA) and attraction to stray $\sigma$ (M tone in CA). Thus the domains predicted by binary feet nicely match up with those required by languages with ternary stress. 
ILT feet provide about four times the number of domains as a theory with only binary feet, ceteris paribus: e.g., foot-initial is one domain if we only have one kind of foot, but four if we have max, min, non-max, and non-min kinds of feet:

(27) $\left(\sigma^{\prime} \sigma\right)_{\max , \min }$

$$
\left(\left(\sigma^{\prime} \sigma\right)_{\min , \text { non-max }} \sigma\right)_{\max , \text { non-min }}
$$

The richer structure of ILT feet predicts more domains. MPK do not detail the number of domains, but based on the domains they do identify, there seem to be 26 (see below). Based on vowel lengthening in CA, for instance, MPK claim that 'the two unstressed syllables in an ILT foot have different structures: each weak syllable is immediately dominated by a different foot projection, and hence the phonology may exploit this structural difference in phonological processes' (2015: 463). There are five distinct projections that can dominate a stressless syllable for MPK $\left.\left.\left.-\sigma)_{\max }, \sigma\right)_{\min }, \sigma\right)_{\text {non-max }}, \sigma\right)_{\text {non-min }}$, and $\left.\sigma\right)_{\omega}$ (for strays)—so phonological processes should be able to exploit these structural differences as well. The same obtains for stressed syllables, except that they are never dominated by non-min or $\omega$ so there are only three types: ó $\left.\left.)_{\max }, \sigma\right)_{\min }, \sigma\right)_{\text {non-max }}$. Similarly, 'languages with non-minimal and minimal feet can potentially exploit this structural difference between the two types of foot-heads' (MP 2013: 47).

The additional structure of ILT feet and the domains provided by max, min, non-max, and non-min yield 26 distinct domains, of which the traditional 6 in (26) form a proper subset:

(28) ILT feet: 26 prosodic domains

$\begin{array}{llll}\text { foot-initial } & \text { foot-medial } & \text { foot-final } \\ \text { max-initial } & \text { max-medial } & \text { max-final } \\ \text { min-initial } & \text { min-medial } & \text { min-final } \\ \text { non-max-initial } & \text { non-max-medial } & \text { non-max-final } & \\ \text { non-min-initial } & \text { non-min-medial } & \text { non-min-final } & \\ \text { max-head } & \text { min-head } & \text { non-max-head } & \text { non-min-head } \\ \text { max-dependent } & \text { min-dependent } & \text { non-max-dependent } & \text { non-min-dependent } \\ \text { double-head } & \text { double-dependent } & \text { stray } \sigma & \end{array}$

MPK use three of these (underlined) for CA fortition, lengthening, and tone: 'We have showed ILT feet to be proper domains for these phenomena allowing maximally simple statements of their contexts, as foot-initial, double-head status and dependent of a non-minimal foot, respectively' (2016: 12, my emphasis). The domains Leer provides for the same processes are no less simple as far as I can tell.

González (2018) provides a survey of 126 consonantal processes that are sensitive to stress, feet, or both, from 78 languages in 37 families. Only 2/126 cases potentially involve ternary feet: aspiration in English and gradation in Nganasan (Helimsky 1998). Aspiration in English is foot initial, either with stressless feet,

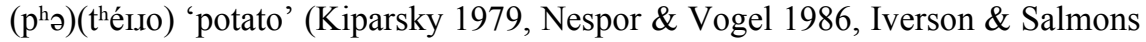
1995), or with recursive feet, (p ${ }^{\text {h}}$ (thé 2005, MPK 2016) but the data doesn't decide the matter either way, and aspiration 
in English doesn't require recursive feet. Gonzáles offers an analysis of Nganasan that does without ternary feet (2018: 173ff.), so it looks like foot-based domains for consonantal processes rarely or never require the 20 extra domains that ILT feet provide - double-head, double-dependent, non-min, non-min-dependent, etc. 'There are consonantal processes that affect just weak footed syllables syllables and not unfooted syllables' (González 2018: 194ff.) but no cases that require more than this. ${ }^{2}$

\subsection{Too many feet}

Abstracting away from quantity, there are three kinds of binary foot ( $\sigma \sigma)$, ( $\sigma \sigma)$, (б) shared by most theories and an additional four types $((\sigma \sigma) \sigma)),(\sigma(\sigma \sigma))),((\sigma \sigma)$ $\sigma)$ ), ( $(\sigma \sigma))$ unique to ILT theory. MPK (2015) have done the field a great service by working out a typology of stress systems that allegedly mix binary and ternary feet. I've tried to condense their many informative tables here with suggestive subsets of their abstract examples including all of the languages they list. They propose 22 types of stress system, over half of which they themselves claim are unattested. Using left-aligned cases to represent the larger typology, let's look at their first eight types:

(29) Typology of mixed foot systems (MPK 2015, condensed)
A $(\sigma \sigma) \sigma \sigma \sigma$
Tunica, Mohawk, Lakota, Atayal
B $(\sigma \sigma)(\sigma \sigma) \sigma$
$(\sigma \sigma \sigma) \sigma \sigma$
Pintupi, Warao, Araucanian, Creek
Macedonian, Choguita Rarámuri
C $(\sigma \sigma)(\sigma \sigma)(\sigma)$
Maranungku, Weri
$(\sigma \sigma)(\sigma \sigma) \sigma$
unattested
$(\sigma \sigma)(\sigma \sigma)(\sigma)$
unattested
D $(\sigma \sigma)(\sigma \sigma)(\sigma \sigma \sigma)$
Garawa, Piro, Pintupi, Araucanian
$(\sigma \sigma)(\sigma \sigma \sigma)(\sigma \sigma)$
findonesian

On the left are the four core cases with many languages in each type, especially B, C, D. Not so for the types on the right, which include ternary feet (the ternary feet in $\mathrm{D}$ are dealt with presently). Macedonian is an extremely complex case (Baerman 1999) but Standard Macedonian has fixed antepenultimate stress, usually analyzed with trochaic feet as befits the secondary stresses found in other dialects. It can of course be treated with a final dactyl, but is generally treated with non-final trochees (Baerman 1999, Buckley 2009). Choguita Rarámuri doesn't seem to belong on this list as far as I can tell as 'the prominence of second syllable... suggests that CR has a left-aligned iambic system' (Caballero 2011: 8). I've struek these languages from the record above, meaning that their stress patterns do not require recursive feet, though they can be modeled with ternary feet if one

2. An anonymous reviewer asks if feet are necessary for any of this, a question I will dodge for lack of space. Like most of us, MPK assume that feet provide prosodic domains for phonological processes. I've tried to show that ternary feet are unnecessary for this, even given that assumption. Of course if no feet are needed, ternary feet are not needed a fortiori. 


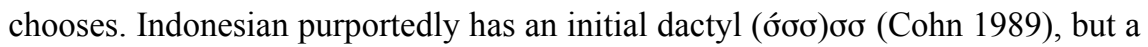
recent study concludes: 'The most important conclusion we draw from the results of our experiments is that there is no reason whatsoever to assume that there is such a thing as word-based stress in Indonesian' (van Zanten \& Goedemans 2009: 221).

The languages in B and D have identical stress patterns: 'Importantly, although the stress pattern is ambiguous between two metrical bracketings (categories B and D) in such cases, non-stress evidence may be available to resolve this ambiguity' (MPK 2015: 479). No such evidence is given, there at least, so the claim that any language fills D rather than B is as yet unsupported. In any case, no stress system requires D.

The other fourteen types are mostly unattested according to MPK and if we take out Kashaya (per Buckley 2019, but see Buckley 2014), Estonian, Chugach, Tripura Bangla, Hocąk, Cayuvava, Gilbertese, and Sentani, as argued above, we are left with no languages to fill out their typology:

(30) Typology of mixed foot systems (continued)

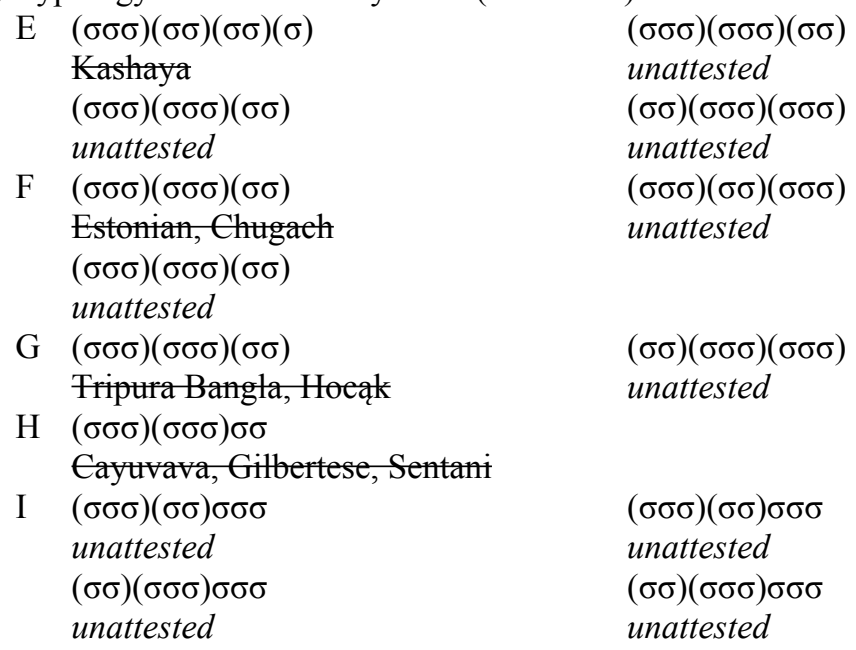

The only well-attested types are the three on the left in A, B, C/D, exactly the set predicted if there are no ternary feet in the languages of the world. The additional eighteen types of stress system are not needed.

Recall, too, that MPK's approach allows for non-minimal feet with skipped syllables, such that $((\sigma \sigma) \sigma) \sigma((\sigma \sigma) \sigma) \sigma \sigma$ is optimal, with quaternary stress, as shown in (4) above. This significantly increases the typology MPK present, adding many

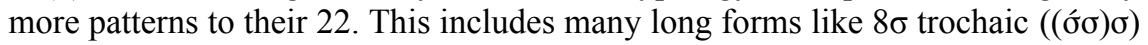
$\sigma((\sigma \sigma) \sigma) \sigma$ with stress on every fourth syllable from the end, but also $8 \sigma$ trochaic $(\sigma(\sigma \sigma)) \sigma(\sigma(\sigma \sigma) \sigma)$, with stress on the antepenult and every fourth syllable preceding it. Similarly for iambic feet. And those cover only the cases without mixed feet. MPK's study claims that languages can mix binary and ternary feet, which is what gives them such a large typological space; add to that the possibility of binary and ternary systems that skip syllables and the size of the space continues to grow. 
Syllable skipping arises whenever foot alignment constraints dominate the constraints that chain (strings of) unparsed syllables to the beginnings and ends of words, MPK's CHAIN-LEFT and CHAIN-RIGHT. In their 'factorial typology' (p. 476ff), MPK consider only those rankings in which either CHAIN-LEFT or CHAINRIGHT is undominated. For this reason, they fail to treat potential cases of syllable skipping (weak local parsing). This has no ill effects for their first two types, corresponding to Tunica and Macedonian, as they have a single foot per word. But consider their rhythmic category B, which covers languages like Pintupi, Warao, Araucanian, and Creek (p. 477ff):

(31) Ranking for $\mathrm{B}\left(\sigma^{*}\right)$ (Pintupi)

CHAIN-R, ALIGN-L/R $\mathrm{R}_{\text {non-min }}$, ALIGN-L/R unary $_{\text {, }}$ TROCHEE, TROCHEE ${ }_{\text {non-min }}, \mathrm{IAMB}_{\text {non-min }} \gg$ CHAIN-L 》

ALIGN-L/R ${ }_{\text {max }}$, ALIGN-L/R min $_{\text {, IAMB }}$

Ranking for $\mathrm{B}\left(\sigma^{*}\right) ; \mathrm{T}$ in $[3 \mathrm{~s}] \omega$ (unattested)

Chain-R, Align-L/ $\mathrm{R}_{\text {non-min }}$, Align-L/R $\mathrm{R}_{\text {unary }}$, TrocheE, IAMB $_{\text {non-min }} \gg$

CHAIN-L 》

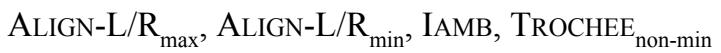

The details are unimportant for the present point, which is that undominated CHAIN-R at the beginning of each ranking above keep away syllable-skipping (weak local parsing) by chaining all stray syllables to the end of the word. MPK's constraint rankings for all of their rhythmic categories, A (21 a-b), B (23a-b), C (25a-b), D (27 a-b), E (29 a-d), F (30 a-c), G (31 a-b), H (32), I (33 a-d), begin with CHAIN-L or CHAIN-R. MPK fail to consider grammars where both CHAIN-L and CHAIN-R are dominated by ALIGN-L or ALIGN-R, i.e., though such grammars must perforce arise in a factorial typology. These grammars are precisely those that yield syllable-skipping.

MPK's 'factorial typology' is thus very much incomplete because it doesn't include cases where both CHAIN-L and CHAIN-R are dominated. This matters because it is those excluded rankings that promote syllable skipping (weak-local parsing) and thereby model ternary stress with binary feet. A full factorial typology of their constraints would make it clear that ternary feet are never needed. Another way of seeing all this is to scan their Tables III-XI to see where stray syllables fall. None of these includes violations of CHAIN-L or CHAIN-R. Consider their Table IV, for instance, repeated below:

(32) $\mathrm{B}^{*}(\sigma)$ (8 subpatterns)

$(\sigma \sigma)$

$(\sigma \sigma) \sigma$

$(\sigma \sigma)(\sigma \sigma)$

$(\sigma \sigma)(\sigma \sigma) \sigma$

$(\sigma \sigma)(\sigma \sigma)(\sigma \sigma)$

$(\sigma \sigma)(\sigma \sigma)(\sigma \sigma) \sigma$

$(\sigma \sigma)(\sigma \sigma)(\sigma \sigma)(\sigma \sigma)$

Pintupi, Warao, Araucanian, Creek
$\mathrm{B}^{*}(\sigma) ; \mathrm{T}$ in $[3 \sigma] \mathrm{W}$ (16 subpatterns)

$(\sigma \sigma)$

$(\sigma \sigma \sigma)$

$(\sigma \sigma)(\sigma \sigma)$

$(\sigma \sigma)(\sigma \sigma) \sigma$

$(\sigma \sigma)(\sigma \sigma)(\sigma \sigma)$

$(\sigma \sigma)(\sigma \sigma)(\sigma \sigma) \sigma$

$(\sigma \sigma)(\sigma \sigma)(\sigma \sigma)(\sigma \sigma)$

unattested 
Again, details and nomenclature are not crucial. What matters is that none of the strings in (32) is parsed with a skipped syllable; unfooted strays are always wordfinal (undomiated CHAIN-R) or word-initial (undominated CHAIN-L, not shown). Allowing for skipped syllables would yield ternary stress with binary feet like the following:

(33) paths untrodden: ternary stress with binary feet
$(\sigma \dot{\sigma})$
$(\sigma \dot{\sigma} \sigma) \sigma$
$(\sigma \sigma)$
$(\sigma \dot{\sigma}) \sigma \sigma$
$\left(\sigma^{\prime} \sigma\right) \sigma(\sigma \dot{\sigma})$
$(\dot{\sigma} \sigma) \sigma(\dot{\sigma} \sigma) \sigma$
$(\dot{\sigma} \sigma) \sigma(\dot{\sigma} \sigma) \sigma \sigma$
$(\sigma \dot{\sigma}) \sigma(\sigma \dot{\sigma}) \sigma\left(\sigma^{\prime} \sigma\right)$
$\left(\sigma \sigma^{\prime}\right) \sigma$
$\left(\sigma \sigma^{\prime}\right) \sigma \sigma$
$\left(\sigma \sigma^{\prime}\right) \sigma\left(\sigma \sigma^{\prime}\right)$
$\left(\sigma \sigma^{\prime}\right) \sigma\left(\sigma \sigma^{\prime}\right) \sigma$
$\left(\sigma \sigma^{\prime}\right) \sigma\left(\sigma \sigma^{\prime}\right) \sigma \sigma$
ternary stress with binary trochees
$\left(\sigma \sigma^{\prime}\right) \sigma\left(\sigma \sigma^{\prime}\right) \sigma\left(\sigma \sigma^{\prime}\right)$
ternary stress with binary iambs

A full factorial typology of MPK's constraints captures ternary stress without ternary feet.

In short, MPK do not present a factorial typology at all. ${ }^{3}$ They propose a typology of rhythmic types (29-30 above) in which there is no syllable skipping and provide OT rankings for each of those types. A factorial typology would work in the other direction: all constraint rankings would be given, yielding a typology of predicted types. This would include constraint rankings in which both CHAIN-L and CHAIN-R are dominated, which would lead to a typology that includes syllable skipping, and thus to a model of ternary stress without ternary feet.

\subsection{Too little recursion}

Recursion results in a lot of structure, to say the least, so MPK adopt 'a few inviolable restrictions which we will tentatively assume to be enforced by GEN' (2015: 466):

(34) Gen: a working hypothesis

a. Feet are maximally binary branching.

b. Recursion at the foot layer is minimal: feet display maximally one layer of recursion.

c. Recursive feet arise by adjunction of a syllable to a foot, i.e. a recursive foot may not branch into two feet: $\left((\sigma \sigma)_{\mathrm{Ft}}(\sigma)_{\mathrm{Ft}}\right)_{\mathrm{Ft}}$ and $\left((\sigma \sigma)_{\mathrm{Ft}}(\sigma \sigma)_{\mathrm{Ft}}\right)_{\mathrm{Ft}}$ are not possible recursive feet.

(a) is a common assumption in phonology, but the stipulations in (b-c) are not shared elsewhere. (b) 'bans quaternary feet, $(((\sigma \sigma) \sigma) \sigma)$, and larger recursive feet

3. I haven't either, as an anonymous reviewer rightly points out. I hope to do this in future work, hopefully in conjunction with Martínez-Paricio \& Kager. 
from GEN' (p. 466) but recursion elsewhere (in phonology, syntax, semantics, math, computer science) is never limited to 'maximally one layer', which seems like a contradiction in terms. (c) 'disallows feet from dominating two feet, i.e. it prohibits BALANCED feet, and only allows UNBALANCED recursive feet in which a foot dominates another foot and a weak syllable' ( $\mathrm{ibid}$.). Again, nothing like this is found elsewhere in language. Adjunction in syntax is always balanced, where phrases adjoin to other phrases, not to heads. This is also true elsewhere in phonology, as MPK make clear: 'Note that these restrictions are specific to the foot: both balanced recursive prosodic structures in which a category $\mathrm{X}$ dominates two categories $\mathrm{X}$ and prosodic structures with more than one layer of recursion have been proposed for higher layers of the prosodic hierarchy (Ladd 1986, Ito \& Mester 2007)' (p. 466). Indeed, balanced feet are commonly thought to be the only type of trochees ( $\mu \mu$ or $\sigma \sigma$, see Hayes 1995), so banishing balanced recursive trochees seems problematic. One additional stipulation from MPK: 'To facilitate our typological research, we have also excluded from GEN candidates with internally layered feet in which a syllable is adjoined to a unary foot (e.g. ((夭)б))' (p. 466), a type included in Kager 2012. I submit that all of this stipulation substantially weakens the argument for recursive feet.

Nor is it clear what all these stipulations buy us, as ILT theory still allows stressless feet, stray syllables, even long strings of stray syllables, and, as I've tried to show, syllable skipping. A broad goal of linguistics is to avoid stipulations and this is especially true of OT (Prince \& Smolensky 1993/2004), which avoids stipulations on GEN by capturing cross-linguistic generalizations with constraint ranking.

Even if we grant all the stipulations, there's a large element of incoherence in the resulting model. Two of the four foot types are headed on the same side, as makes sense: iambic $(\sigma(\sigma \sigma))$ is right-headed inside and out just as trochaic $((\sigma \sigma) \sigma))$ is left-headed. The first is arguably an iamb-within-an-iamb and the second a trocheewithin-a-trochee. But the other recursive feet have mixed headedness: $((\sigma \sigma) \sigma))$ is right-headed on the inside and left-headed on the outside, $(\sigma(\sigma \sigma)))$ is left-headed on the inside and right-headed on the outside. This is clear from the trees MPK use, in which 'headedness is indicated with vertical lines' (MPK 2016: 5), e.g.,

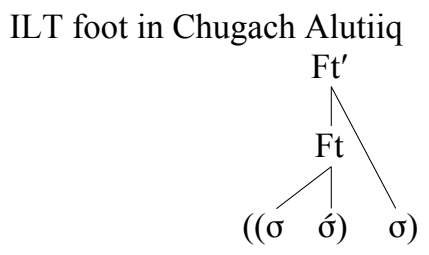

The minimal foot above is iambic and the non-minimal foot is trochaic (MPK 2015: 474) yet they are meant to be projections of the same foot, which is incoherent. Elsewhere in recursive phonology different headedness is evidence that two categories are distinct, as we expected:

Might the phrase just be a higher projection of the word? Again this can only be decided on empirical grounds: For example, Kahncmuyipour's (2003) finding that stress in 
Persian involves opposite headedness at the word and at the phrase level argues that we are dealing with different units of prosody. (Itô \& Mester 2012: 288, my emphasis)

MPK allow min and non-min feet to be differently headed and to serve as prosodic domains for different processes. This makes them equivalent to traditional superfeet, which have no recursion. ILT feet seem to be recursive in name only: they differ from superfeet only in how the nodes are labeled.

A recent article on recursion in linguistics carries the worrisome title "When linguists talk about mathematical logic' (Lobina 2014). Another is 'Syntactic Structures and recursive devices: a legacy of imprecision' (Tomalin 2011). As a field, we do not do well in using mathematical notions and Tomalin warns that

the notion of 'recursion' was fundamentally ambiguous when it began to be used by linguists in the 1950s, and (as the subtitle of this article implies), these ambiguities have persisted to the present day. This unfortunate (and needless) perpetuation of imprecision has had a deleterious impact upon recent discussions of the role of recursion in linguistic theory. (p. 298)

The explosion of 'recursion' in recent phonology is (even) less well-grounded than it is in syntax. Lobina notes that

The conflation between recursive mechanisms and recursive structures is the main problem with the manner in which cognitive science at large treats the concept of recursion... mathematicians restrict the recursive property to functions or rules, it is never applied to objects. (2014: 12)

We should ask, then, What kind of recursion is intended by ILT feet? Here's what we have to choose from:

Self-reference, I submit, is the property that underlies what recursion is, it is its denotation. As such, it can apply to different theoretical constructs, its connotations, thereby accounting for the fact that we have recursively-defined functions in mathematics (i.e., functions defined in terms of previously calculated values), and recursive procedures (evaluation procedures that involve architecturally-equivalent sub-operations), recursive processes (wherein operations call themselves, generating chains of deferred operations), and recursive structures (objects in which an X is constitutive of a larger X) in computer science. The real issue is to not conflate these notions, for it is that error that creates the most confusion in the literature. (Lobina 2014: 13)

My guess is that we're to take ILT feet as recursive structures, where $\mathrm{X}$ is constitutive of a larger $\mathrm{X}$. But that would require that the Xs have the same properties, that they be the same kind of thing, and this is clearly not the case for ILT feet. We've just seen that the most basic of foot relations, headedness, need not be the same for ILT feet, showing that ILT feet are not actually recursive: a right-headed structure inside of a left-headed structure is X-in-Y, not X-in-X. ILT footing is simply embedding (which is ubiquitous in phonology), but not self-embedding and so probably not recursion (unless they mean some other kind of recursion than self-embedding). 
Another indication that ILT feet are not self-embedded is that the constraints that regulate them crucially target different parts of the foot. ALIGN-L([Ft $\left.{ }_{\max }\right]_{\omega}, \mathrm{Ft}$, $\omega)$ targets only maximal feet and ALIGN-L([Ft $\left.\left.{ }_{\text {min }}\right]_{\omega}, \mathrm{Ft}, \omega\right)$ targets only minimal feet; this only makes sense if $\mathrm{Ft}_{\text {max }} \neq \mathrm{Ft}_{\text {min }}$, which again shows that $\left(\mathrm{Ftmax}_{\mathrm{Ftmin}}(\ldots)\right)$ does not involve self-embedding. To work as they are intended to work, ILT feet must define distinct structures; they are not self-embedded structures.

Yet another way we can see that recursive feet don't involve self-embedding is that they are proposed as domains for distinct processes, as we've seen. If $\mathrm{X}$ and $\mathrm{Y}$ are different sizes, have different headedness, and call up different phonological processes, there's no meaningful sense in which $\mathrm{X}=\mathrm{Y}$. I submit that ILT are defined and used in ways that involve mere embedding; they involve no selfembedding and no recursion in any other sense. Similar issues arise for notions like 'recursive prosodic word', as argued by Vigario $(2010)$, Vogel $(2012,2019)$, and Downing \& Kadenge (2020), among others.

Further afield, the kind of recursion proposed recently for phonology is nothing like the recursion established for syntax. In syntax, there is no direct recursion of one category within itself, e.g., $\left({ }_{\mathrm{PP}}\left({ }_{\mathrm{PP}} \ldots\right)\right)$ or $\left(_{\mathrm{NP}}\left({ }_{\mathrm{NP}} \ldots\right)\right)$; recursion always involves an intermediary category, e.g., $\left({ }_{\mathrm{PP}}\left({ }_{\mathrm{NP}} \ldots\right)\right)$ or $\left({ }_{\mathrm{NP}}\left({ }_{\mathrm{pP}} \ldots\right)\right)$, as Arsenijevic \& Hinzen 2012 have shown. Weirdly, in recent proposals for phonology, there is only direct recursion of one category within itself and recursion never involves an intermediate category: $\varphi$-in- $\varphi$ (feet, MPK 2015), $\omega$-in- $\omega$ (prosodic words, Inkelas 1990), $\Phi$-in- $\Phi$ (phonological phrases, Itô \& Mester 2009), ı-in-ı (intonation phrases, Ladd 1986), exactly the opposite of what we find in syntax.

\section{Conclusion}

There are numerous extant analyses of CA, TB, and Cayuvava that forgo ternary feet in general and recursive feet in particular, similarly for less solid cases of ternarity like Estonian and Hocąk. In that sense it is obvious that no stress system requires recursive feet. In any case, constraints that align feet to word edges minimize feet (Ishii 1996) and thus promote skipping; so the very constraints MPK use in their analysis undermine the need for the ILT feet they espouse. I've tried to show that prosodic domains for fortition, lenition, and other phonological processes in these and other languages do not require recursive feet either. In all, it seems there is no data that requires ILT feet.

In addition, recursive feet bring with them a number of theoretical problems. They predict many more prosodic domains than we need and far more kinds of foot than the stress patterns of natural languages use. As phonological constructs they are highly stipulative and unlike recursive structures elsewhere in mathematics and cognitive science. Finally, the inner and outer parts of an ILT foot are typically domains for distinct phonological processes, are targeted as distinct objects by constraints, and may differ in headedness. In sum, they behave exactly like nonrecursive superfeet and are recursive in name only. 


\section{References}

Anttila, Arto \& Young-mee Yu Cho. 1998. Variation and change in optimality theory. Lingua 104: 31-56.

Arsenijevic, Boban \& Wolfram Hinzen. 2012. On the absence of X-within-X recursion in human grammar. Linguistic Inquiry, 43(3): 423-440.

Beasley, Tim \& Katherine Crosswhite. 2003. Avoiding boundaries: antepenultimate stress in a rule-based framework. Linguistic Inquiry 34(3): 361-392.

Bennett, Ryan. 2012. Foot-conditioned phonotactics and prosodic constituency. University of California Santa Cruz dissertation.

Bennett, Ryan. 2018. Recursive prosodic words in Kaqchikel (Mayan). Glossa: A journal of general linguistics 3(1): 67, 1-33.

Blevins, Juliette \& Sheldon P. Harrison. 1999. Trimoraic feet in Gilbertese. Oceanic Linguistics 38(2): 203-230.

Buckley, Eugene. 2009. Locality in metrical phonology. Phonology 26: 389-435.

Buckley, Eugene. 2014. Kashaya extrametricality and formal symmetry. Supplemental Proceedings of Phonology 2013.

Buckley, Eugene. 2019. Kashaya foot extrametricality as post-accentuation. Proceedings, Annual Meeting in Phonology.

Caballero, Gabriela. 2011. Morphologically conditioned stress assignment in Choguita Rarámuri (Tarahumara). Linguistics 49: 749-790.

Caballero, Gabriela \& Lucien Carroll. 2015. Tone and stress in Choguita Rarámuri (Tarahumara) word prosody. IJAL 81(4), 457-493.

Cohn, Abigail. 1989. Stress in Indonesian and bracketing paradoxes. NLLT 7: 167-216.

Das, Shyamal. 2001. Some aspects of the phonology of Tripura Bangla and Tripura Bangla English. PhD dissertation, CIEFL Hyderabad. Available as ROA-493 from the Rutgers Optimality Archive.

Davis, Stuart \& Mi-Hui Cho. 2003. The distribution of aspirated stops and $/ \mathrm{h} / \mathrm{in}$ American English and Korean: an alignment approach with typological implications. Linguistics 41(4): 607-652.

Davis, Stuart. 2005. "Capitalistic" vs. "Militaristic": the paradigm uniformity effect reconsidered. In Laura Downing, T. A. Hall \& Renate Raffelsieffen (eds.). Paradigms in phonological theory, 107-121. Oxford: Oxford University Press.

Downing, Laura J. \& Maxwell Kadenge. 2020. Re-placing PStem in the prosodic hierarchy. The Linguistic Review 37(3): 433-461.

Eek, Arvo. 1990. Units of temporal organisation and word accents in Estonian. Linguistica Uralica: 251-262.

Elfner, Emily. 2012. Syntax-prosody interactions in Irish. Doctoral dissertation, University of Massachusetts, Amherst.

Ellison, T. Mark. 1994. Phonological derivation in Optimality Theory. In Proceedings of the 15th International Conference on Computational Linguistics (COLING). Kyoto, 1007-1013.

Golston, Chris. 1990. Floating H and L* tones in ancient Greek. Arizona Phonology Conference, Vol. 3. ed. by James Myers and Patricia E. Perez, 66-82. Tucson, AZ.

González, Carolina. 2018. A typology of stress- and foot-sensitive consonantal phenomena. International Journal of Basque Linguistics and Philology-Anuario del Seminario de Filología Vasca Julio de Urquijo, 87-210. 
Halle, Morris \& Jean-Roger Vergnaud. 1987. An essay on stress. Cambridge: MIT Press. Hammond, Michael. 1990. Deriving ternarity. Coyote Papers: Working Papers in Linguistics from A-Z. University of Arizona Linguistics Circle, 39-58.

Haraguchi, Shosuke. 1991. A theory of stress and accent. Berlin: De Gruyter, Inc.

Hayes, Bruce. 1995. Metrical stress theory: Principles and case studies. Chicago: University of Chicago Press.

Helmbrecht, Johannes \& Christian Lehmann (eds.). 2006. Learners' Dictionary HocankEnglish / English-Hocank. (= Arbeitspapiere des Seminars für Sprachwissenschaft der Universität Erfurt; 21). Erfurt: University of Erfurt. Retrieved from $<$ http:// www2.uni-erfurt.de/sprachwissenschaft/ASSidUE/ASSidUE21.pdf>.

Hewitt, Mark S. 1994. Binarity and ternarity in Alutiiq. In Jean Ann and Kyoko Yoshimura (eds.). Proceedings of Arizona Phonology Conference 4, 44-60. University of Arizona.

Hint, Mati. 1973. Eesti keele sõnafonoloogia. [Word phonology of Estonian.] Vol. 1: Rõhusüsteemi fonoloogia ja morfofonoloogia põhiprobleeemid. [The main phonological and morphological problems of the Estonian stress system.] Tallinn: Eeste NSV Teaduste Akadeemia.

Houghton, Paula. 2006. Ternary stress. Ms, University of Massachusetts, Amherst. Available as ROA-836 from the Rutgers Optimality Archive.

Hyde, Brett. 2012. Alignment constraints. NLLT 30: 1-48.

Idsardi, William J. 2008. Calculating metrical structure. In Eric Raimy \& Charles E. Cairns (eds.). Contemporary views on architecture and representations in phonology, 191-212. Cambridge, Mass.: MIT Press.

Inkelas, Sharon. 1990. Prosodic constituency in the lexicon. Outstanding Dissertations in Linguistics Series. New York: Garland Publishing Co.

Ishii, Toru. 1996. An optimality theoretic approach to ternary stress systems. In Brian Agbayani and N. Harada (eds.). Proceedings of the South Western Optimality Theory Workshop (SWOT II). University of California Irvine Working Papers in Linguistics 2: 95-111.

Iverson, Gregory K. \& Joseph C. Salmons. 1995. Aspiration and laryngeal representation in Germanic. Phonology 12: 369-396.

Jensen, John. 2000. Against ambisyllabicity. Phonology 17: 187-235.

Kager, René. 1993. Alternatives to the iambic-trochaic law. NLLT 11: 381-432.

Kager, René. 1994. Ternary rhythm in alignment theory. Manuscript, Utrecht University. Available as ROA-35 from the Rutgers Optimality Archive.

Key, Harold H. 1961. Phonotactics of Cayuvava. IJAL 27: 143-150.

Key, Harold H. 1963/1967. Morphology of Cayuvava. Doctoral dissertation, University of Texas, Austin. Published 1967 as Morphology of Cayuvava. The Hague: Mouton.

Key, Mary Ritchie. 2015. Cayuvava dictionary. In Mary Ritchie Key \& Bernard Comrie (eds.) The Intercontinental Dictionary Series. Leipzig: Max Planck Institute for Evolutionary Anthropology. Retrieved from $<$ http://ids.clld.org/contributions/283>.

Kiparsky, Paul. 1979. Metrical structure assignment is cyclic. LI 10: 421-441.

Krauss, Michael (ed.). 1985. Yupik Eskimo prosodic systems: descriptive and comparative studies. Fairbanks, Alaska: Alaska Native Language Center, University of Alaska.

Ladd, D. Robert. 1986. Intonational phrasing: the case for recursive prosodic structure. Phonology Yearbook 3: 311-340. 
Leben, William. 1973/1980. Suprasegmental phonology. Outstanding Dissertations in Linguistics. New York: Garland Press.

Leer, Jeff. 1985a. Prosody in Alutiiq. In Krauss (ed.). Yupik Eskimo prosodic systems: descriptive and comparative studies, 77-134. Fairbanks, Alaska: Alaska Native Language Center, University of Alaska.

Leer, Jeff. 1985b. Evolution of prosody in the Yupik languages. In Krauss (ed.). Yupik Eskimo prosodic systems: descriptive and comparative studies, 135-158. Fairbanks, Alaska: Alaska Native Language Center, University of Alaska.

Leer, Jeff. 1985c. Toward a metrical interpretation of Yupik prosody. In Krauss (ed.). Yupik Eskimo prosodic systems: descriptive and comparative studies, 159-173. Fairbanks, Alaska: Alaska Native Language Center, University of Alaska.

Leer, Jeff. 1993/4. The phonology of the Kenai Peninsula dialect of Chugach Alutiiq. In O. Miyaoka \& F. Endo (eds.). Languages of the North Pacific Rim, Vol. 7, 45-148. Tokyo: ELPR. Retrieved from <https://uafanlc.alaska.edu/Online/SUC972L1993/ SUC972L1993.pdf>.

Levin, Juliette. 1985. Evidence for ternary feet and implications for a metrical theory of stress rules. Ms., University of Texas, Austin.

Martínez-Paricio, Violeta. 2013. An exploration of minimal and maximal metrical feet. Doctoral dissertation, University of Tromsø.

Martínez-Paricio, Violeta \& René Kager. 2015. The binary-to-ternary rhythmic continuum in stress typology: Layered feet and nonintervention constraints. Phonology 32(3): 459-504.

Martínez-Paricio, Violeta \& René Kager. 2016. Metrically conditioned pitch and layered feet in Chugach Alutiiq. Loquens 3(2): e030.

$<$ http://dx.doi.org/10.3989/loquens.2016.030>

McCarthy, John J. 2003. OT constraints are categorical. Phonology 20(1): 75-138.

McCarthy, John J. \& Alan Prince. 1993. Generalized alignment. Yearbook of Morphology 12: 79-153.

Nespor, Marina \& Irene Vogel. 1986. Prosodic phonology. Dordrecht: Foris.

Prince, Alan \& Paul Smolensky. 1993/2004. Optimality Theory: constraint interaction in generative grammar. Ms, Rutgers University \& University of Colorado, Boulder. Published 2004, Malden, Mass. \& Oxford: Blackwell.

Prince, Alan. 1980. A metrical theory for Estonian quantity. Linguistic Inquiry 11: 511-562.

Rice, Curt. 2011. Ternary rhythm. In Marc van Oostendorp, Colin J. Ewen, Elizabeth Hume, and Keren Rice (eds.). The Blackwell companion to phonology, Vol. 5, 1228-1244. Malden, MA: Blackwell.

Selkirk, Elisabeth. 2011. The syntax-phonology interface. In John Goldsmith, Jason Riggle and Alan Yu (eds). The Handbook of Phonological Theory, $2^{\text {nd }}$ edition, 435-484. Oxford: Blackwell Publishing.

Tomalin, Marcus. 2011. Syntactic Structures and recursive devices: a legacy of imprecision. Journal of Logic, Language and Information 20: 297-315.

$<$ https://doi.org/10.1007/s10849-011-9141-1>

Vigário, Marina. 2010. Prosodic structure between the prosodic word and the phonological phrase: Recursive nodes or an independent domain? The Linguistic Review 27: 485-530. 
Vogel, Irene. 2012. Recursion in phonology? In Bert Botma \& Roland Noske (eds.). Phonological Architecture: Empirical, Theoretical and Diachronic Issues, 41-61. Berlin: De Gruyter.

Vogel, Irene. 2019. Life after the strict layer hypothesis. In Hongming Zhang (ed.). Prosodic studies: Challenges and prospects, 9-60. London: Routledge

van Zanten, Ellen \& Rob Goedemans. 2009. Prominence in Indonesian: stress, phrases, and boundaries. Wacana 11(2): 197-225. 
